\title{
Effect of dietary cadmium and/or lead on histopathological changes in the kidneys and liver of bank voles Myodes glareolus kept in different group densities
}

\author{
Aneta Salińska - Tadeusz Włostowski • \\ Elżbieta Zambrzycka
}

Accepted: 14 July 2012/Published online: 2 August 2012

(C) The Author(s) 2012. This article is published with open access at Springerlink.com

\begin{abstract}
Bank voles free living in a contaminated environment are known to be more sensitive to cadmium (Cd) toxicity than the rodents exposed to $\mathrm{Cd}$ under laboratory conditions, but the reasons for this difference are poorly defined. The present work was designed to determine whether dietary lead $(\mathrm{Pb})$, a common environmental co-contaminant, and/or animal density that affects various physiological processes, would influence susceptibility to Cd toxicity in the kidneys and liver of these animals. For 6 weeks, the female bank voles were kept individually or in a group of six and provided with diet containing environmentally relevant concentrations of $\mathrm{Cd}[<0.1 \mu \mathrm{g} / \mathrm{g}$ (control) and $60 \mu \mathrm{g} / \mathrm{g}$ dry wt $]$ and $\mathrm{Pb}[<0.2 \mu \mathrm{g} / \mathrm{g}$ (control) and $300 \mu \mathrm{g} / \mathrm{g}$ dry wt] alone or in combination. At the end of exposure period, histopathology and analyses of metallothionein, glutathione and zinc that are linked to a protective effect against $\mathrm{Cd}$ toxicity, as well as $\mathrm{Cd}, \mathrm{Pb}$, copper, iron and lipid peroxidation were carried out. Histopathological changes in the kidneys (a focal glomerular swelling and proximal tubule degeneration) and liver (a focal hepatocyte swelling, vacuolation and inflammation) occurred exclusively in some bank voles kept in a group and exposed to $\mathrm{Cd}$ alone (2/6) or $\mathrm{Cd}+\mathrm{Pb}(4 / 6)$. The observed toxicity in grouped bank voles appeared not to be based on altered (1) tissue disposition of $\mathrm{Cd}$ and/or $\mathrm{Pb}$, (2) metallothionein, glutathione and zinc concentrations, or (3) tissue copper, iron and lipid peroxidation. The data indicate that high
\end{abstract}

\footnotetext{
A. Salińska $\cdot$ T. Włostowski ( $₫)$

Institute of Biology, University of Białystok, Świerkowa 20B,

15-950 Białystok, Poland

e-mail: twlostow@uwb.edu.pl

E. Zambrzycka

Institute of Chemistry, University of Białystok, Hurtowa 1, 15-950 Białystok, Poland
}

population density in combination with environmental $\mathrm{Pb}$ may be responsible for an increased susceptibility to $\mathrm{Cd}$ toxicity observed in bank voles free living in a contaminated environment; the mechanism by which animal density affects Cd toxicity deserves further study.

Keywords Cadmium - Lead · Metallothionein · Histopathology $\cdot$ Lipid peroxidation · Animal density

\section{Introduction}

Cadmium $(\mathrm{Cd})$ and lead $(\mathrm{Pb})$ are important toxic metals occurring in the environment naturally and as pollutants emanating mainly from industrial sources (Liu 2003; Satarug et al. 2003; Thévenod 2009). Environmental Cd has been proven to induce damage primarily to the kidneys, including tubular degeneration, interstitial inflammation, apoptosis and glomerular swelling in wildlife such as seabirds-Fulmaris glacialis (Nicholson et al. 1983), ptarmigan Lagopus leucurus (Larison et al. 2000), roe deer Capreolus capreolus (Beiglböck et al. 2002) and magpies Pica pica (Włostowski et al. 2010). Similar histopathological changes typical for $\mathrm{Cd}$ toxicity have been found in the kidneys of small mammals such as yellow-necked mice Apodemus flavicolis, bank voles, wood mice Apodemus sylvaticus and white-toothed shrews Crocidura russula free living in an area polluted with heavy metals (DamekPoprawa and Sawicka-Kapusta 2003, 2004; SanchezChardi et al. 2009). Those studies also revealed that wild animals inhabiting polluted sites are more susceptible to $\mathrm{Cd}$ toxicity than those exposed to the metal under laboratory conditions. For example, in the free-living bank voles from an industrialized area renal injury occurs at the $\mathrm{Cd}$ level lower than $20 \mu \mathrm{g} / \mathrm{g}$ wet wt (Damek-Poprawa and Sawicka- 
Kapusta 2004), while in the laboratory voles the nephropathy is evident only when the $\mathrm{Cd}$ concentration exceeds $50 \mu \mathrm{g} / \mathrm{g}$ wet wt (Włostowski et al. 2004). Still, the reason for this difference in sensitivity to Cd intoxication remains to be determined.

Noteworthy, in small mammals inhabiting an industrialized area not only accumulation of $\mathrm{Cd}$ but also appreciable concentrations of $\mathrm{Pb}$ in the kidneys have been detected (Damek-Poprawa and Sawicka-Kapusta 2003, 2004). It is also known from animal studies that chronic exposure to $\mathrm{Pb}$ can lead to nephropathy, including nephromegaly and dysfunction of proximal tubules (Liu et al. 2012; Qu et al. 2002). In addition, combined exposure to $\mathrm{Pb}$ and $\mathrm{Cd}$ has been shown to exacerbate cytotoxicity in the rat proximal tubular cells (Wang et al. 2011). However, it is unknown whether environmental $\mathrm{Pb}$ can produce or only enhance existing $\mathrm{Cd}$-induced renal damage in the wild animals (Damek-Poprawa and Sawicka-Kapusta 2003, 2004).

It is important to point out that free-ranging animals, compared to those raised in laboratory, are concurrently subjected to other stressful conditions, including changes in food resources, threats from predators, and interaction with conspecifics (Beiglböck et al. 2002; Damek-Poprawa and Sawicka-Kapusta 2004; Pollock and Machin 2009; Tidhar et al. 2007). In general, every individual encounters stress originating from interaction with conspecifics, especially when population density is high (Marchlewska-Koj et al. 1994; Pollock and Machin 2009). It has been demonstrated that the psychosocial stress resulting from crowding can modify growth, reproduction, behavior, immune function and other physiological processes in various species, including the bank vole (Grippo et al. 2010; MarchlewskaKoj et al. 1994, 2003; Tort et al. 1996; Vicario et al. 2012). However, the role of animal density or interaction with conspecifics in Cd toxicity remains unknown.

Therefore, the present work was designed to determine whether dietary $\mathrm{Pb}$ and/or animal density would influence Cd toxicity in the kidneys and liver of bank voles [Myodes (=Clethrionomys) glareolus] that appeared to be vulnerable to the metal toxicity when free living in a contaminated area (Damek-Poprawa and Sawicka-Kapusta 2004). The toxicity was evaluated by assessing kidney and liver histopathology. In addition, analyses of metallothionein (MT), glutathione $(\mathrm{GSH}), \mathrm{Cd}, \mathrm{Pb}$, zinc $(\mathrm{Zn})$, copper $(\mathrm{Cu})$, iron $(\mathrm{Fe})$ and lipid peroxidation were carried out to find out whether $\mathrm{Pb}$ and/or animal density affect sensitivity to $\mathrm{Cd}$ toxicity (if any) by modulating MT induction, GSH metabolism, Cd kinetics or trace element concentrations and oxidative stress. All the examined processes and elements are commonly thought to be important ones during development of Cd toxicity. Specifically, MT, GSH and Zn are linked to a protective effect against $\mathrm{Cd}$ toxicity (Chan and Cherian 1992; Jacquillet et al. 2006; Jihen et al. 2008; Klaassen et al. 2009; Tang et al. 1998), while $\mathrm{Cu}, \mathrm{Fe}$ and oxidative stress are considered to be responsible for the progression of toxicity (Liu et al. 2009; Thévenod and Friedmann 1999; Whittaker et al. 2011).

\section{Materials and methods}

Animals and experimental design

The bank vole is a common European rodent that has become a model for ecological and ecotoxicological experiments. Field and laboratory studies revealed that population density affects particularly female voles, including their reproduction and behavior (MarchlewskaKoj et al. 1994, 2003). Therefore, female bank voles (1 month old, weighing 11-13 g), being the $F_{1}$ offspring of the wild-caught stock (Knyszyn Old Forest, north-eastern Poland) were used throughout the study. The bank voles were randomly divided into two groups according to the cage density: (1) one vole per cage [low density group (LD)], and (2) six voles per cage [high density group (HD)]. At the beginning of the experiment each density group was divided into four subgroups $(n=6$ each) according to dietary $\mathrm{Cd}$ and $\mathrm{Pb}$ : (1) control, (2) $\mathrm{Cd}-60$ $\mu \mathrm{g} / \mathrm{g}$, (3) $\mathrm{Pb}-300 \mu \mathrm{g} / \mathrm{g}$, and (4) $\mathrm{Cd}-60 \mu \mathrm{g} / \mathrm{g}+\mathrm{Pb}-$ $300 \mu \mathrm{g} / \mathrm{g}$ dry wt. The animals were housed for 6 weeks in stainless-steel cages $(44 \times 27 \times 20 \mathrm{~cm}$ ) (lined with peat as absorptive material) at $18-20{ }^{\circ} \mathrm{C}$ on 12 light/dark cycle and at 50-70\% relative humidity. They received ad libitum distilled water and control or $\mathrm{Cd}$ - and $\mathrm{Pb}$-containing whole wheat grains, which appeared to be an adequate quality food for these rodents (Włostowski et al. 2004). In addition, an identical quantity of apple was offered to all voles ( $3 \mathrm{~g} / \mathrm{vole} / \mathrm{week}$ ), who ate it completely. The food intake was monitored throughout the experiment. Prior to the experiment the grains were contaminated with $\mathrm{Cd}$ and/ or $\mathrm{Pb}$ [soaked in $\mathrm{CdCl}_{2}$ or $\mathrm{Pb}\left(\mathrm{NO}_{3}\right)_{2}$ solutions]. Atomic absorption spectrophotometry (AAS) analysis of the grains revealed that actual levels of $\mathrm{Cd}$ were between 58 and $63 \mu \mathrm{g} / \mathrm{g}$ (Cd groups) and those for $\mathrm{Pb}$ were $280-310 \mu \mathrm{g} / \mathrm{g}$ dry wt $(\mathrm{Pb}$ groups). Control grains contained less than $0.1 \mu \mathrm{g} \mathrm{Cd} / \mathrm{g}$ and $0.2 \mu \mathrm{g} \mathrm{Pb} / \mathrm{g}$. The concentrations of $\mathrm{Zn}, \mathrm{Cu}$ and $\mathrm{Fe}$ in the grains were 22-26, 4-6 and 80-100 $\mu \mathrm{g} / \mathrm{g}$ dry wt, respectively. The concentrations of dietary $\mathrm{Cd}$ and $\mathrm{Pb}$ were two-fold higher than those observed in a heavily contaminated environment (Liu 2003) and chosen to obtain more pronounced results.

At the end of the 6-week exposure period, the bank voles were weighed, killed by decapitation and the liver and kidneys were removed, rinsed in cold saline, and blotted dry on absorbent paper. Blood was also taken to 
determine hemoglobin and hematocrit by using standard methods (spectrophotometrically as cyanmethemoglobin at $540 \mathrm{~nm}$ and hematocrit centrifuge, respectively). One kidney and a portion of the fresh liver $(0.25 \mathrm{~g})$ were transferred to $1.0 \mathrm{ml}$ chilled $0.25 \mathrm{M}$ sucrose and homogenized with a Teflon pestle in a glass homogenizer. Aliquots $(0.5$ and $0.1 \mathrm{ml})$ of the homogenate were taken for determination of metal concentrations and lipid peroxidation, respectively. The remaining homogenate was centrifuged at $20,000 \times g$ for $20 \mathrm{~min}$ at $4{ }^{\circ} \mathrm{C}$, and the resulting supernatant was removed for MT and GSH assays.

\section{Histological examination}

One kidney and a portion of the liver were fixed in $4 \%$ formaldehyde, dehydrated in ethanol and xylene, embedded in paraffin, cut into $5-\mu \mathrm{m}$ sections, and stained with hematoxylin and eosin for microscopic examination.

\section{Metal determination}

Metal determinations were performed as described recently (Salińska et al. 2012). The homogenate $(0.5 \mathrm{ml})$ was placed in a glass tube with $2.0 \mathrm{ml}$ of concentrated nitric acid. After $20 \mathrm{~h}$ of sample digestion at room temperature, $72 \%$ perchloric acid $(0.5 \mathrm{ml})$ was added and the mixture was heated at $100{ }^{\circ} \mathrm{C}$ for $3 \mathrm{~h}$. Finally, the temperature was raised to 150-180 ${ }^{\circ} \mathrm{C}$ and digestion continued for another $2 \mathrm{~h}$. Deionized water was added to the residue $(0.1 \mathrm{ml})$ after digestion to a volume of $3.0 \mathrm{ml}$ (first solution). A portion of the first solution $(200 \mu \mathrm{l})$ was evaporated to dryness in a quartz crucible at $130{ }^{\circ} \mathrm{C}$, and the residue was redissolved in an appropriate amount of deionized water (second solution). $\mathrm{Cd}$ and $\mathrm{Pb}$ analyses of these solutions were carried out by electrothermal AAS using a Solaar M6 instrument with a Zeeman correction. The concentrations of $\mathrm{Zn}, \mathrm{Cu}$ and $\mathrm{Fe}$ in the first solution were determined by AAS in an air-acetylene flame with a deuterium correction. Quality assurance procedures included the analysis of reagent blanks and appropriate standard reference material (NIST bovine liver $1577 b$ ). The recovery of $\mathrm{Cd}, \mathrm{Pb}, \mathrm{Zn}, \mathrm{Cu}$ and $\mathrm{Fe}$ were 91-93, 105-115, 90-95, 89-95 and 95-101\%, respectively.

\section{MT determination}

MT in the kidneys and liver was determined by a Cdsaturation method (Włostowski et al. 2004). Briefly, a $0.1 \mathrm{ml}$ sample was incubated in a $1.5-\mathrm{ml}$ vial for $10 \mathrm{~min}$ at room temperature with $1.0 \mathrm{ml}$ Tris- $\mathrm{HCl}$ buffer $(0.03 \mathrm{M}$, $\mathrm{pH}$ 7.8) containing $1.0 \mu \mathrm{g} \mathrm{Cd} / \mathrm{ml}$. To remove non-MTbound $\mathrm{Cd}$, bovine hemoglobin (Sigma) $(0.1 \mathrm{ml}$ of a $5 \%$ solution in $\mathrm{H}_{2} \mathrm{O}$ ) was added and the sample was heated for
$1.5 \mathrm{~min}$ at $95{ }^{\circ} \mathrm{C}$, cooled, and centrifuged for $5 \mathrm{~min}$ at $10.000 \times g$. Addition of hemoglobin, heating, and centrifugation of the sample was repeated twice. $\mathrm{Cd}$ bound to MT in the resulting clear supernatant was determined by electrothermal AAS. MT content was expressed in $\mu \mathrm{g}$ of the protein per gram of wet tissue, assuming that $1 \mathrm{~mol}$ of MT (6600) binds $7 \mathrm{~mol}$ of $\mathrm{Cd}$. Cd bound to MT in the kidneys and liver was determined by using the same method but without $\mathrm{Cd}$ saturation. $\mathrm{Cd}$ not bound to MT was defined as the difference between the total tissue $\mathrm{Cd}$ and the $\mathrm{Cd}$ bound to MT.

\section{GSH assay}

The total GSH (reduced + oxidized) was measured in the postmitochondrial fraction according to the method of Tietze (1969) by using NWLSS Glutathione Assay Kit (Vancouver, WA, USA). Briefly, an aliquot of the supernatant $(50 \mu \mathrm{l})$ was deproteinized by adding $100 \mu \mathrm{l}$ of an aqueous solution of $5 \%$ metaphosphoric acid. After centrifugation an aliquot $(25 \mu \mathrm{l})$ of the supernatant was diluted by adding $500 \mu \mathrm{l}$ of assay buffer. To $400 \mu \mathrm{l}$ of this solution $400 \mu \mathrm{l}$ of assay buffer, $50 \mu \mathrm{l}$ of $5,5^{\prime}$-dithiobis-2-nitrobenzoic acid (DTNB) and $50 \mu \mathrm{l}$ of GSH reductase in assay buffer were added and incubated for $2 \mathrm{~min}$ and $30 \mathrm{~s}$ at room temperature. Subsequently $50 \mu \mathrm{l}$ of NADPH solution was added and the reduction rate of DTNB into 5-thio-2nitrobenzoic acid (TNB) was measured spectrophotometrically at $412 \mathrm{~nm}$ for $3 \mathrm{~min}$. GSH was expressed as $\mu \mathrm{mol} / \mathrm{g}$ wet weight.

\section{Lipid peroxidation assay}

Lipid peroxidation was assessed by measuring malondialdehyde formation, using the thiobarbituric acid assay (Ohkawa et al. 1979). To $0.1 \mathrm{ml}$ of the tissue homogenate, $0.2 \mathrm{ml}$ of $8.1 \%$ sodium dodecyl sulfate, $1.5 \mathrm{ml}$ of $20 \%$ acetic acid, $1.5 \mathrm{ml}$ of $0.8 \%$ TBA and $0.6 \mathrm{ml}$ of distilled water were added and vortexed. The reaction mixture was placed in a water bath at $95{ }^{\circ} \mathrm{C}$ for $1 \mathrm{~h}$. After cooling, $1.0 \mathrm{ml}$ of distilled water and $5.0 \mathrm{ml}$ of butanol/pyridine mixture $(15: 1 \mathrm{v} / \mathrm{v})$ were added and vortexed. After centrifugation, absorbance of the organic phase was determined at $532 \mathrm{~nm}$. Tetraethoxypropane was used to prepare a calibration curve. The results were expressed as TBAreacting substances (nmol/g wet weight).

Statistical analysis

Data were expressed as mean \pm SD. The effects of $\mathrm{Cd}$ and $\mathrm{Pb}$ were tested by means of two-way analysis of variance (ANOVA) in the bank voles kept individually (Group 1) or in a group of six (Group 2). Differences between the groups 
and subgroups were analyzed by one-way ANOVA followed by the Duncan's multiple range test (SPSS 14.0). Differences at $P<0.05$ were considered statistically significant.

\section{Results}

Subchronic consumption of dietary $\mathrm{Cd}$ and $\mathrm{Pb}$ alone or in combination had no effect on body weight (Table 1) and food intake ( $0.15-0.18 \mathrm{~g} / \mathrm{g}$ body $\mathrm{wt} / \mathrm{day})$ in the bank voles kept individually (LD voles) or in a group of six (HD voles). Although enlarged kidneys are indicative of chronic $\mathrm{Cd}$ and $\mathrm{Pb}$ toxicity (Liu et al. 2000; Qu et al. 2002), in the present study subchronic $\mathrm{Cd}$ and $\mathrm{Pb}$ alone or in combination did not affect the kidneys or liver weights in bank voles from the two cage density groups (Table 1). Despite the fact that exposure to $\mathrm{Cd}$ and $\mathrm{Pb}$ can result in decreased hemoglobin and hematocrit values (Whittaker et al. 2011; Włostowski et al. 2000), no changes of these indices were observed in the LD- and HD bank voles exposed to dietary $\mathrm{Cd}$ and/or $\mathrm{Pb}$ (Table 1).

The histopathological changes in the kidneys and liver are shown in Figs. 1 and 2, respectively. The kidneys and liver of control LD- and HD bank voles showed normal morphology (Figs. 1a, 2a). Likewise, the normal morphology was found in all LD bank voles exposed to $\mathrm{Cd}$ and/or $\mathrm{Pb}$ (Table 1). In contrast, treatment with $\mathrm{Cd}$ alone produced a focal proximal tubule degeneration (Fig. 1b) and glomerular swelling (Fig. 1c) in the kidneys, and a focal hepatocyte swelling (Fig. 2b), vacuolation and inflammation (leukocyte infiltration) (Fig. 2c) in the liver of two (per six) HD voles (Table 1). The same changes were observed in four (per six) HD animals exposed simultaneously to $\mathrm{Cd}$ and $\mathrm{Pb}$; a normal histological picture of the kidneys and liver was noted in the grouped bank voles exposed only to dietary $\mathrm{Pb}$ (Table 1 ). Despite the occurrence of histopathology, renal and hepatic lipid peroxidation was not significantly affected by $\mathrm{Cd}, \mathrm{Pb}$ and interaction between these metals $(P>0.1)$ in the two density groups (Tables 2, 3).

The concentrations of renal and hepatic MT were significantly affected only by dietary $\mathrm{Cd}(P<0.0001)$ (Tables 2, 3). The MT levels in the kidneys and liver of HD bank voles did not differ from those of the respective LD animals. Likewise, the accumulation of $\mathrm{Cd}$ in the kidneys and liver was also influenced only by dietary $\mathrm{Cd}$ $(P<0.0001)$ and reached similar level in the LD- and HD bank voles (Tables 2, 3). Assuming that $1 \mathrm{~mol}$ of MT (6600) binds $7 \mathrm{~mol}$ of $\mathrm{Cd}$, the Cd-binding capacity of MT exceeded the total concentration of $\mathrm{Cd}$ by $1-8 \mu \mathrm{g} / \mathrm{g}$ in the kidneys and by $7-10 \mu \mathrm{g} / \mathrm{g}$ in the liver. Despite this, the fraction of renal and hepatic $\mathrm{Cd}$ not bound to MT amounted to $25-30 \%$ of the total tissue $\mathrm{Cd}$ in all bank voles exposed to dietary $\mathrm{Cd}$ or $\mathrm{Cd}+\mathrm{Pb}$ (Tables 2,3 ).

Neither dietary $\mathrm{Cd}$ alone and $\mathrm{Pb}$ alone nor in combination affected significantly $(P>0.1)$ the concentration of GSH in the liver of bank voles from the two density groups (Table 3). The renal GSH could not be detected by the method used, probably because of too small sample mass.

Subchronic consumption of $\mathrm{Cd}$, either alone or in combination with $\mathrm{Pb}$, increased significantly $(P<0.0000)$ $\mathrm{Zn}$ concentrations in the kidneys and liver of bank voles from the two density groups (Tables 2, 3). In general, the tissue $\mathrm{Zn}$ followed a pattern similar to that of MT concentration. The renal and hepatic $\mathrm{Cu}$ as well as the renal $\mathrm{Fe}$ were not affected $(P>0.1)$ by dietary $\mathrm{Cd}$ and/or $\mathrm{Pb}$, whereas the hepatic Fe decreased 2-3-fold upon the exposure to $\mathrm{Cd}$ alone or $\mathrm{Cd}+\mathrm{Pb}$ in the $\mathrm{LD}$ - and $\mathrm{HD}$ bank voles (Tables 2, 3). In addition, the concentrations of $\mathrm{Pb}$ in

Table 1 Body and organ weights, hematological values, and incidence of histopathological changes in the kidneys and liver of female bank voles exposed to dietary $\mathrm{Cd}$ and/or $\mathrm{Pb}$ and raised individually or in a group of six

\begin{tabular}{|c|c|c|c|c|c|}
\hline Subgroup & Bady mass (g) & Kidneys mass (g) & Liver mass (g) & Hemoglobin $(\mathrm{g} / 100 \mathrm{ml})$ & Hematocrit (\% \\
\hline \multicolumn{6}{|c|}{ Group 1: One vole per cage (six cages/subgroup) } \\
\hline Control & $14.9 \pm 0.7$ & $0.16 \pm 0.01(0 / 6)$ & $0.55 \pm 0.04(0 / 6)$ & $15.3 \pm 1.1$ & $48.0 \pm 2.4$ \\
\hline $\mathrm{Cd}$ & $15.1 \pm 1.7$ & $0.17 \pm 0.02(0 / 6)$ & $0.69 \pm 0.18(0 / 6)$ & $16.8 \pm 1.0$ & $50.1 \pm 2.1$ \\
\hline $\mathrm{Pb}$ & $15.3 \pm 1.8$ & $0.18 \pm 0.01(0 / 6)$ & $0.62 \pm 0.11(0 / 6)$ & $16.7 \pm 1.3$ & $50.9 \pm 1.4$ \\
\hline $\mathrm{Cd}+\mathrm{Pb}$ & $16.4 \pm 0.9$ & $0.18 \pm 0.01(0 / 6)$ & $0.66 \pm 0.09(0 / 6)$ & $16.6 \pm 1.4$ & $51.7 \pm 2.9$ \\
\hline \multicolumn{6}{|c|}{ Group 2: Six voles per cage (one cage/subgroup) } \\
\hline Control & $15.6 \pm 0.8$ & $0.16 \pm 0.01(0 / 6)$ & $0.57 \pm 0.04(0 / 6)$ & $15.5 \pm 1.0$ & $49.0 \pm 2.0$ \\
\hline $\mathrm{Cd}$ & $15.1 \pm 0.5$ & $0.17 \pm 0.01(2 / 6)$ & $0.51 \pm 0.03(2 / 6)$ & $15.1 \pm 0.7$ & $48.3 \pm 1.5$ \\
\hline $\mathrm{Pb}$ & $15.2 \pm 0.7$ & $0.17 \pm 0.01(0 / 6)$ & $0.60 \pm 0.08(0 / 6)$ & $16.2 \pm 1.1$ & $49.0 \pm 2.5$ \\
\hline $\mathrm{Cd}+\mathrm{Pb}$ & $15.9 \pm 0.8$ & $0.18 \pm 0.02(4 / 6)$ & $0.59 \pm 0.11(4 / 6)$ & $15.9 \pm 1.3$ & $50.1 \pm 2.0$ \\
\hline
\end{tabular}

Values represent the mean $\pm \mathrm{SD}$ for $n=6$. Bank voles received, for 6 weeks, control diet or diets containing $60 \mu \mathrm{g} \mathrm{Cd} / \mathrm{g}$ and/or $300 \mu \mathrm{g} \mathrm{Pb} / \mathrm{g}$. In parentheses the number of voles with histopathological changes per total number of animals is presented (see Figs. 1, 2). There were no statistically significant differences between the groups and subgroups 

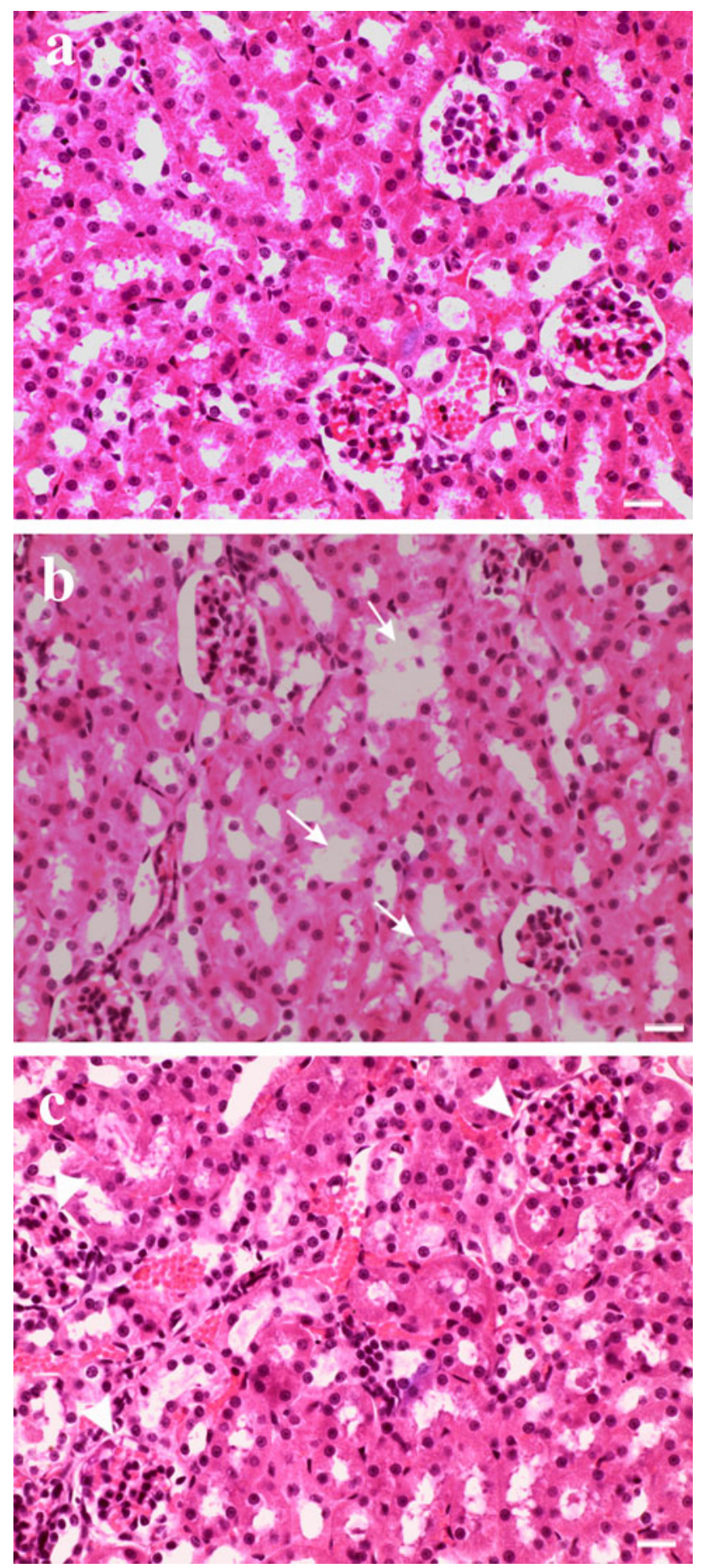

Fig. 1 Representative photomicrographs of kidney section from (a) control bank voles, and (b, c) bank voles raised in a group of six and exposed to dietary $\mathrm{Cd}$ [b tubule degeneration (arrows), c glomerular swelling (arrowhead)]. Scale bar, $20 \mu \mathrm{m}$

the kidneys and liver of bank voles exposed to $\mathrm{Pb}$ alone or in combination with $\mathrm{Cd}$ were similar $(P>0.1)$ in the two density groups, but the renal $\mathrm{Pb}$ was six-fold higher than that in the liver (Tables 2, 3).
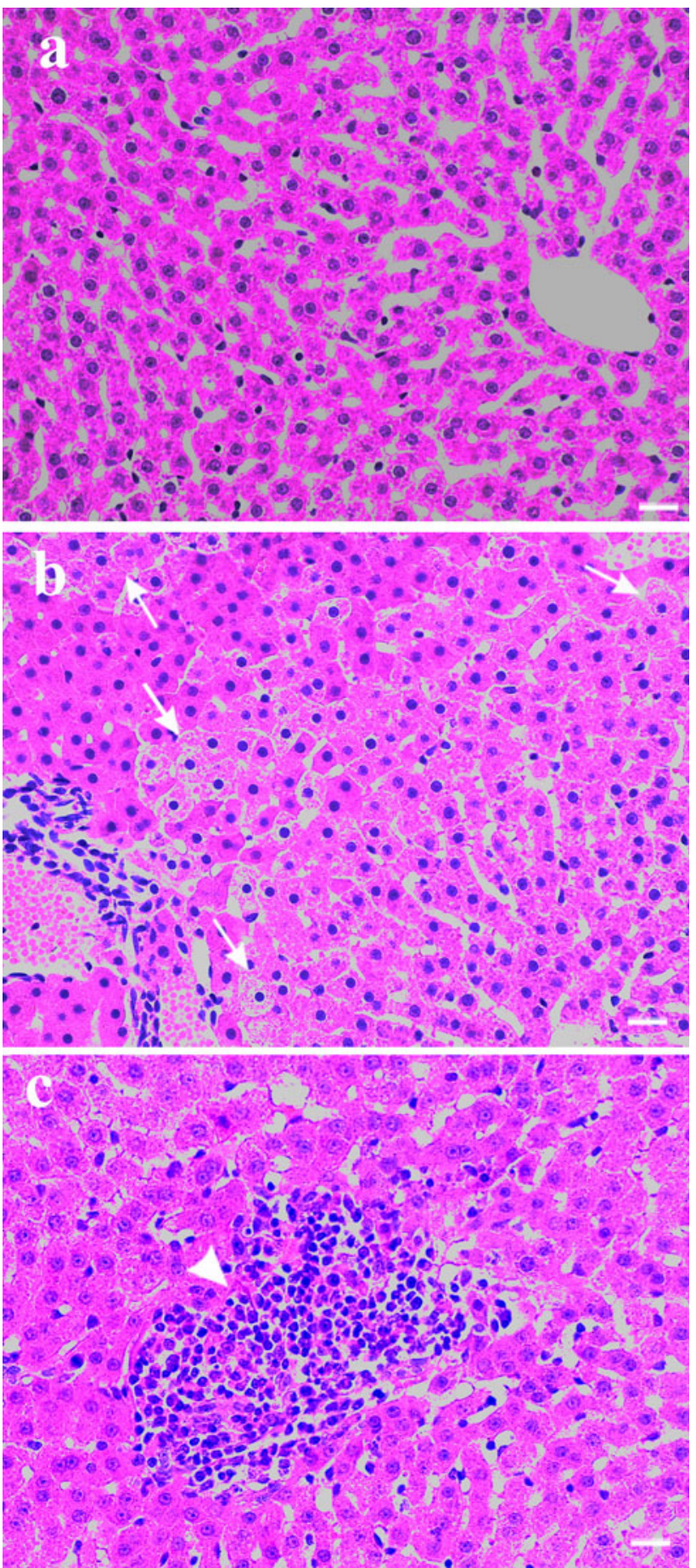

Fig. 2 Representative photomicrographs of liver section from (a) control bank voles, and (b, c) bank voles raised in a group of six and exposed to dietary Cd [b hepatocyte swelling (arrows), c leukocyte infiltration (arrowhead)]. Scale bar, $20 \mu \mathrm{m}$

\section{Discussion}

The present study demonstrates that relatively high dietary $\mathrm{Cd}$ alone produces histopathological changes in the kidneys and liver of some bank voles kept in a group but not in 
Table 2 Metallothionein and metal concentrations, and lipid peroxidation (TBARS) in the kidneys of female bank voles exposed to dietary Cd and/or $\mathrm{Pb}$ and raised individually or in a group of six

\begin{tabular}{|c|c|c|c|c|c|c|c|}
\hline Subgroup & $\begin{array}{l}\text { Metallothionein } \\
(\mu \mathrm{g} / \mathrm{g} \text { wet } \mathrm{wt})\end{array}$ & $\begin{array}{l}\text { Cadmium } \\
\text { ( } \mu \mathrm{g} / \mathrm{g} \text { wet wt) }\end{array}$ & $\begin{array}{l}\text { Zinc } \\
(\mu \mathrm{g} / \mathrm{g} \text { wet wt) }\end{array}$ & $\begin{array}{l}\text { Copper } \\
\text { ( } \mu \mathrm{g} / \mathrm{g} \text { wet wt) }\end{array}$ & $\begin{array}{l}\text { Iron } \\
\text { ( } \mu \mathrm{g} / \mathrm{g} \text { wet } \mathrm{wt})\end{array}$ & $\begin{array}{l}\text { Lead } \\
\text { ( } \mu \mathrm{g} / \mathrm{g} \text { wet wt) }\end{array}$ & $\begin{array}{l}\text { TBARS } \\
\text { (nmol/g wet wt) }\end{array}$ \\
\hline \multicolumn{8}{|c|}{ Group 1: One vole per cage (six cages/subgroup) } \\
\hline Control & $14.9 \pm 3.0 \mathrm{a}$ & $0.36 \pm 0.08 \mathrm{a}$ & $15.7 \pm 4.2 \mathrm{a}$ & $5.2 \pm 0.7 \mathrm{a}$ & $102 \pm 10 \mathrm{a}$ & $0.56 \pm 0.10 \mathrm{a}$ & $142 \pm 30 \mathrm{a}$ \\
\hline $\mathrm{Cd}$ & $311 \pm 25 b$ & $33.2 \pm 6.7 b(9.0)$ & $29.5 \pm 3.8 b$ & $5.0 \pm 0.4 \mathrm{a}$ & $95 \pm 11 \mathrm{a}$ & $0.53 \pm 0.18 \mathrm{a}$ & $144 \pm 17 \mathrm{a}$ \\
\hline $\mathrm{Pb}$ & $15.6 \pm 1.5 \mathrm{a}$ & $0.37 \pm 0.07 \mathrm{a}$ & $16.0 \pm 2.6 \mathrm{a}$ & $5.4 \pm 0.9 \mathrm{a}$ & $96 \pm 18 \mathrm{a}$ & $12.7 \pm 1.2 \mathrm{~b}$ & $135 \pm 30 \mathrm{a}$ \\
\hline $\mathrm{Cd}+\mathrm{Pb}$ & $300 \pm 15 b$ & $28.1 \pm 7.2 b(7.0)$ & $26.2 \pm 3.0 \mathrm{~b}$ & $5.2 \pm 0.3 \mathrm{a}$ & $92 \pm 15 a$ & $11.2 \pm 2.0 \mathrm{~b}$ & $160 \pm 15 \mathrm{a}$ \\
\hline \multicolumn{8}{|c|}{ Group 2: Six voles per cage (one cage/subgroup) } \\
\hline Control & $14.2 \pm 3.2 \mathrm{a}$ & $0.35 \pm 0.05 \mathrm{a}$ & $15.4 \pm 3.7 \mathrm{a}$ & $5.1 \pm 0.7 \mathrm{a}$ & $92 \pm 15 a$ & $0.49 \pm 0.15 \mathrm{a}$ & $140 \pm 10 \mathrm{a}$ \\
\hline $\mathrm{Cd}$ & $293 \pm 31 b$ & $32.0 \pm 4.2 b(8.9)$ & $26.3 \pm 3.6 b$ & $5.7 \pm 0.8 \mathrm{a}$ & $91 \pm 10 \mathrm{a}$ & $0.56 \pm 0.11 \mathrm{a}$ & $130 \pm 12 \mathrm{a}$ \\
\hline $\mathrm{Pb}$ & $15.3 \pm 2.5 \mathrm{a}$ & $0.35 \pm 0.06 a$ & $16.5 \pm 2.5 \mathrm{a}$ & $5.4 \pm 0.5 a$ & $94 \pm 12 \mathrm{a}$ & $13.1 \pm 2.5 b$ & $139 \pm 15 a$ \\
\hline $\mathrm{Cd}+\mathrm{Pb}$ & $297 \pm 30 \mathrm{~b}$ & $34.2 \pm 6.7 \mathrm{~b}(8.5)$ & $25.0 \pm 3.5 b$ & $5.3 \pm 0.4 \mathrm{a}$ & $88 \pm 10 \mathrm{a}$ & $10.5 \pm 2.0 \mathrm{~b}$ & $150 \pm 21 \mathrm{a}$ \\
\hline
\end{tabular}

Values represent the mean $\pm \mathrm{SD}$ for $n=6$. Bank voles received, for 6 weeks, control diet or diets containing $60 \mu \mathrm{g} \mathrm{Cd} / \mathrm{g}$ and/or $300 \mu \mathrm{g} \mathrm{Pb} / \mathrm{g}$. In parentheses mean concentration of $\mathrm{Cd}$ not bound to MT is shown. Means in the same column marked with a different letter are significantly different $(P<0.05)$

Table 3 Metallothionein, glutathione and metal concentrations, and lipid peroxidation (TBARS) in the liver of female bank voles exposed to dietary $\mathrm{Cd}$ and/or $\mathrm{Pb}$ and raised individually or in a group of six

\begin{tabular}{|c|c|c|c|c|c|c|c|c|}
\hline Subgroup & $\begin{array}{l}\text { Metallothionein } \\
(\mu \mathrm{g} / \mathrm{g} \text { wet } \mathrm{wt})\end{array}$ & $\begin{array}{l}\text { Cadmium } \\
(\mu \mathrm{g} / \mathrm{g} \text { wet wt })\end{array}$ & $\begin{array}{l}\text { Zinc } \\
(\mu \mathrm{g} / \mathrm{g} \text { wet wt })\end{array}$ & $\begin{array}{l}\text { Copper } \\
\text { ( } \mu \mathrm{g} / \mathrm{g} \text { wet wt) }\end{array}$ & $\begin{array}{l}\text { Iron } \\
(\mu \mathrm{g} / \mathrm{g} \text { wet wt) }\end{array}$ & $\begin{array}{l}\text { Lead } \\
(\mu \mathrm{g} / \mathrm{g} \text { wet wt })\end{array}$ & TBARS (nmol/g wet wt) & $\begin{array}{l}\text { Glutathione } \\
\text { ( } \mu \mathrm{mol} / \mathrm{g} \text { wet wt })\end{array}$ \\
\hline \multicolumn{9}{|c|}{ Group 1: One vole per cage (six cages/subgroup) } \\
\hline Control & $4.9 \pm 0.4 \mathrm{a}$ & $0.13 \pm 0.02 \mathrm{a}$ & $23.2 \pm 2.1 \mathrm{a}$ & $3.6 \pm 0.2 \mathrm{a}$ & $316 \pm 128 \mathrm{a}$ & $0.35 \pm 0.15 \mathrm{a}$ & $108 \pm 32 \mathrm{a}$ & $6.5 \pm 2.0 \mathrm{a}$ \\
\hline $\mathrm{Cd}$ & $238 \pm 66 b$ & $21.8 \pm 5.4 \mathrm{~b}(5.7)$ & $34.5 \pm 5.1 \mathrm{~b}$ & $3.7 \pm 0.4 \mathrm{a}$ & $110 \pm 30 b$ & $0.33 \pm 0.10 \mathrm{a}$ & $93 \pm 8 \mathrm{a}$ & $7.5 \pm 1.6 \mathrm{a}$ \\
\hline $\mathrm{Pb}$ & $4.8 \pm 0.5 \mathrm{a}$ & $0.15 \pm 0.02 \mathrm{a}$ & $24.7 \pm 2.6 \mathrm{a}$ & $3.8 \pm 0.7 \mathrm{a}$ & $349 \pm 130 \mathrm{a}$ & $1.90 \pm 0.50 \mathrm{~b}$ & $101 \pm 17 \mathrm{a}$ & $6.2 \pm 2.2 \mathrm{a}$ \\
\hline $\mathrm{Cd}+\mathrm{Pb}$ & $235 \pm 15 b$ & $20.5 \pm 3.0 \mathrm{~b}(5.9)$ & $34.2 \pm 5.6 \mathrm{~b}$ & $3.5 \pm 0.5 \mathrm{a}$ & $135 \pm 45 b$ & $1.80 \pm 0.50 \mathrm{~b}$ & $95 \pm 10 \mathrm{a}$ & $7.5 \pm 1.5 \mathrm{a}$ \\
\hline \multicolumn{9}{|c|}{ Group 2: Six voles per cage (one cage/subgroup) } \\
\hline Control & $5.1 \pm 0.5 \mathrm{a}$ & $0.12 \pm 0.02 \mathrm{a}$ & $24.2 \pm 4.5 \mathrm{a}$ & $3.8 \pm 0.5 \mathrm{a}$ & $237 \pm 60 \mathrm{a}$ & $0.30 \pm 0.10 \mathrm{a}$ & $106 \pm 17 \mathrm{a}$ & $6.7 \pm 3.0 \mathrm{a}$ \\
\hline $\mathrm{Cd}$ & $243 \pm 19 b$ & $20.7 \pm 3.9 b(5.2)$ & $34.2 \pm 4.9 \mathrm{~b}$ & $3.9 \pm 0.6 \mathrm{a}$ & $100 \pm 25 b$ & $0.35 \pm 0.11 \mathrm{a}$ & $96 \pm 11 \mathrm{a}$ & $7.2 \pm 2.0 \mathrm{a}$ \\
\hline $\mathrm{Pb}$ & $5.0 \pm 0.6 \mathrm{a}$ & $0.14 \pm 0.03 \mathrm{a}$ & $23.9 \pm 2.1 \mathrm{a}$ & $3.8 \pm 0.4 \mathrm{a}$ & $300 \pm 70 \mathrm{a}$ & $1.85 \pm 0.70 \mathrm{~b}$ & $108 \pm 10 \mathrm{a}$ & $6.4 \pm 1.8 \mathrm{a}$ \\
\hline $\mathrm{Cd}+\mathrm{Pb}$ & $260 \pm 34 b$ & $21.0 \pm 4.1 \mathrm{~b}(5.9)$ & $36.3 \pm 5.5 b$ & $3.7 \pm 0.3 \mathrm{a}$ & $130 \pm 35 b$ & $1.70 \pm 0.65 b$ & $97 \pm 15 a$ & $7.4 \pm 2.2 \mathrm{a}$ \\
\hline
\end{tabular}

Values represent the mean $\pm \mathrm{SD}$ for $n=6$. Bank voles received, for 6 weeks, control diet or diets containing $60 \mu \mathrm{g} \mathrm{Cd} / \mathrm{g}$ and/or $300 \mu \mathrm{g} \mathrm{Pb} / \mathrm{g}$. In parentheses mean concentration of $\mathrm{Cd}$ not bound to MT is shown. Means in the same column marked with a different letter are significantly different $(P<0.05)$

those raised individually. In contrast, dietary $\mathrm{Pb}$ alone does not induce any renal and hepatic injury in the two density groups but in combination with $\mathrm{Cd}$ appears to increase the frequency of Cd-induced histopathological changes only in the grouped animals. These findings suggest that high population density or interaction with conspecifics in combination with environmental $\mathrm{Pb}$ may increase susceptibility to Cd toxicity observed in bank voles free living in a contaminated environment (Damek-Poprawa and Sawicka-Kapusta 2004).

There are several potential explanations for the nephroand hepatotoxicity developed during exposure to $\mathrm{Cd}$ alone or co-exposure to $\mathrm{Cd}$ and $\mathrm{Pb}$ exclusively in the grouped bank voles, including toxicokinetic and toxicodynamic interactions. However, the toxicity does not appear to occur at the toxicokinetic level, as tissue accumulation of both $\mathrm{Cd}$ and $\mathrm{Pb}$ was similar, when given alone or together, in bank voles raised in a group or individually (Tables 2, 3). Likewise, the renal and hepatic MT, a primary component of acquired tolerance to toxic effects of $\mathrm{Cd}$ (Klaassen et al. 2009), as well as the fraction of non-MT-bound $\mathrm{Cd}$ [thought as the toxic species (Goyer et al. 1989; Sudo et al. 1996)] were similar in the respective voles from the two density groups. These findings exclude the possibility that the occurrence of histopathology in the grouped animals was due to insufficient amount of the protein or too high content of the non-MT-bound Cd. Similarly, GSH that is known to provide protection against $\mathrm{Cd}$ toxicity (Chan and 
Cherian 1992) could have only a negligible effect because its content was relatively stable in all bank voles exposed to $\mathrm{Cd}$ and/or $\mathrm{Pb}$ (Table 3). It seems also unlikely that the increased kidney and liver injury from $\mathrm{Cd}$ and $\mathrm{Pb}$ coexposure in the grouped bank voles was owing to increased oxidative stress [thought to be a cellular mechanism of toxicity (Thévenod and Friedmann 1999; Wang et al. 2011)], as the renal and hepatic lipid peroxidation as well as the concentrations of prooxidant elements such as $\mathrm{Cu}$ and $\mathrm{Fe}$ (Whittaker et al. 2011) were similar in respective animals from the two groups. Furthermore, renal and hepatic $\mathrm{Zn}$ that is well known as an antioxidant and protects against $\mathrm{Cd}$ toxicity (Jacquillet et al. 2006; Jihen et al. 2008), increased to the same level in the grouped and individual bank voles exposed to dietary $\mathrm{Cd}$ alone or in combination with $\mathrm{Pb}$ (Tables 2, 3). This implies that the fraction of $\mathrm{Zn}$, which most likely was sequestered by MT [specifically by binding sites not occupied by $\mathrm{Cd}$ (see "Results" section)], was ineffective in protection against the toxicity. Overall, although the precise basis for the nephro- and hepatotoxicity produced by $\mathrm{Cd}$ alone or in combination with $\mathrm{Pb}$ only in the grouped bank voles cannot be defined from the present work, it does not appear to be based on altered (1) tissue disposition of $\mathrm{Cd}$ and/or $\mathrm{Pb}$, (2) MT, GSH, and Zn concentrations, or (3) tissue $\mathrm{Cu}, \mathrm{Fe}$ and lipid peroxidation.

The present study also indicates that environmentally relevant concentration of dietary $\mathrm{Pb}$ only increases the frequency of Cd-induced damage to the kidneys and liver of grouped bank voles. This remains in some contrast to other studies indicating that $\mathrm{Cd}$ and $\mathrm{Pb}$ can produce toxicity in additive or synergistic manner both in vivo and in vitro (Wang et al. 2010, 2011). It is also evident from those studies that oxidative stress may be induced by the two metals. In this regard, $\mathrm{Cd}$ and $\mathrm{Pb}$ co-exposure produces significantly more lipid peroxidation in the kidneys of rats than either inorganic given alone (Wang et al. 2010). In the present work $\mathrm{Cd}$ alone and $\mathrm{Pb}$ alone or in combination did not affect lipid peroxidation in the kidneys and liver of bank voles, suggesting no involvement of this process in the injury. Other studies have also contested the main role of lipid peroxidation in cell injury induced by Cd (Stacey et al. 1980; Włostowski et al. 2000, 2010). Sill, these data do not exclude the possibility that the two metals could induce oxidative stress, but the process could not be revealed by using only TBARS assay, which appears to have some limitations, especially when the whole tissue is examined (Meagher and FitzGerald 2000).

Although the cause for the observed difference in susceptibility to Cd-induced renal and hepatic injury between the two density groups of bank voles remains unknown, it cannot be ruled out that the difference could potentially be associated with the negative interaction between animals within a group. It is well known that the interaction with conspecifics can induce psychosocial stress, resulting in various pathophysiological processes (Grippo et al. 2010; Marchlewska-Koj et al. 1994; Tort et al. 1996; Vicario et al. 2012). Specifically, the stress has been shown to alter morphology of mitochondria (swelling and loss of cristae) as well as the activity of citrate synthase, leading to less number of viable mitochondria (Vicario et al. 2010, 2012). Interestingly, similar changes in the morphology of mitochondria were observed in the kidneys of rats upon exposure to $\mathrm{Cd}$ and/or $\mathrm{Pb}$ (Wang et al. 2010). Thus, it is reasonable to assume that the combined exposure to the stress and metals could exacerbate the injury to mitochondria, resulting in pronounced reduction of ATP synthesis. An ATP deprivation, in turn, could cause the loss of ionic control and the cellular disintegration (Cannino et al. 2009; Nicholson et al. 1983); the presence of hepatocyte swelling (Fig. 2b) in the grouped bank voles exposed to $\mathrm{Cd}$ alone or $\mathrm{Cd}+\mathrm{Pb}$ might support the assumption. However, further investigations are needed to clarify the role of psychosocial stress in the metal toxicity in bank voles and other species.

In summary, the results of the present work indicate that high animal density in combination with dietary $\mathrm{Pb}$ markedly exacerbates $\mathrm{Cd}$ toxicity in the kidneys and liver of bank voles. This effect does not appear to involve altered toxicokinetic as well as tissue trace element and lipid peroxidation, and occurs despite sufficiently high concentrations of MT. The mechanism by which animal density affects $\mathrm{Cd}$ toxicity deserves further study.

Ethics All experimental procedures were approved by the Local Ethical Committee (Medical University of Białystok) and were compatible with the standards of the Polish Law on Experimenting on Animals, which implements the European Communities Council Directive (86/609/EEC).

Conflict of interest The authors declare that they have no conflict of interest.

Open Access This article is distributed under the terms of the Creative Commons Attribution License which permits any use, distribution, and reproduction in any medium, provided the original author(s) and the source are credited.

\section{References}

Beiglböck C, Steineck T, Tataruch F, Ruf T (2002) Environmental cadmium induces histopathological changes in kidneys of roe deer. Environ Toxicol Chem 21:1811-1816

Cannino G, Ferrugia E, Luparello C, Rinaldi AM (2009) Cadmium and mitochondria. Mitochondrion 9:377-384. doi:10.1016/ j.mito.2009.08.009

Chan HM, Cherian MG (1992) Protective roles of metallothionein and glutathione in hepatotoxicity of cadmium. Toxicology 72 : 281-290. doi:10.1016/0300-483X(92)90179-I 
Damek-Poprawa M, Sawicka-Kapusta K (2003) Damage to the liver, kidney, and testis with reference to burden of heavy metals in yellow-necked mice from areas around steelworks and zinc smelters in Poland. Toxicology 186:1-10. doi:10.1016/S0300483X(02)00595-4

Damek-Poprawa M, Sawicka-Kapusta K (2004) Histopathological changes in the liver, kidney and testes of bank voles environmentally exposed to heavy metal emission from the steelworks and zinc smelter in Poland. Environ Res 96:72-78. doi:10.1016/ j.envres.2004.02.003

Goyer RA, Miller CR, Zhu SY, Victery W (1989) Non-metallothionein-bound cadmium in the pathogenesis of cadmium nephrotoxicity in the rat. Toxicol Appl Pharmacol 101:232-244. doi:10.1016/0041-008X(89)90272-X

Grippo AJ, Sgoifo A, Mastorci F, McNeal N, Trahanas DM (2010) Cardiac dysfunction and hypothalamic activation during a social crowding stressor in prairie voles. Auton Neurosci 156:44-50. doi:10.1016/j.autneu.2010.03.003

Jacquillet G, Barbier O, Cougnon M, Tanc M, Namorado MC, Martin D, Reyes JL, Poujeol P (2006) Zinc protects renal function during cadmium intoxication in the rat. Am J Physiol Renal Physiol 290:F127-F137. doi:10.1152/ajprenal.00366.2004

Jihen EH, Imed M, Fatima H, Kerkeni A (2008) Protective effects of selenium $(\mathrm{Se})$ and zinc $(\mathrm{Zn})$ on cadmium $(\mathrm{Cd})$ toxicity in the liver and kidney of the rat: histology and $\mathrm{Cd}$ accumulation. Food Chem Toxicol 46:3522-3527. doi:10.1016/j.fct.2008.08.037

Klaassen CD, Liu J, Diwan BA (2009) Metallothionein protection of cadmium toxicity. Toxicol Appl Pharmacol 238:215-220. doi:10.1016/j.taap.2009.03.026

Larison JR, Likens GE, Fitzpatrick JW, Crock JG (2000) Cadmium toxicity among wildlife in the Colorado Rocky Mountains. Nature 406:181-183. doi:10.1038/35018068

Liu ZP (2003) Lead poisoning combined with cadmium in sheep and horses in the vicinity of non-ferrous metal smelters. Sci Total Environ 309:117-126. doi:10.1016/S0048-9697(03)00011-1

Liu J, Liu Y, Habeebu SM, Waalkes MP, Klaassen CD (2000) Chronic combined exposure to cadmium and arsenic exacerbates nephrotoxicity, particularly in metallothionein-I/II null mice. Toxicology 147:157-166. doi:10.1016/S0300483X(00)00194-3

Liu J, Qu W, Kadiiska MB (2009) Role of oxidative stress in cadmium toxicity and carcinogenesis. Toxicol Appl Pharmacol 238:209-214. doi:10.1016/j.taap.2009.01.029

Liu CM, Ma JQ, Sun YZ (2012) Puerarin protects rat kidney from lead-induced apoptosis by modulating the PI3K/Akt/eNOS pathway. Toxicol Appl Pharmacol 258:330-342. doi:10.1016/ j.taap.2011.11.015

Marchlewska-Koj A, Pochron E, Galewicz-Sojecka A, Galas J (1994) Suppression of estrus I female mice by presence of conspecifics or by foot shock. Physiol Behav 55:317-321

Marchlewska-Koj A, Kapusta J, Kruczek M (2003) Prenatal stress modifies behavior in offspring of bank voles (Clethironomys glareolus). Physiol Behav 79:671-678. doi:10.1016/S0031-9384 (03)00168-9

Meagher E, FitzGerald GA (2000) Indices of lipid peroxidation in vivo: strengths and limitations. Free Radic Biol Med 28: 1745-1750. doi:10.1016/S0891-5849(00)00232-X

Nicholson JK, Kendall MD, Osborn D (1983) Cadmium and mercury nephrotoxicity. Nature 304:633-635

Ohkawa H, Ohishi N, Yagi K (1979) Assay of lipid peroxides in animal tissues by thiobarbituric acid reaction. Anal Biochem 95:351-358

Pollock B, Machin KL (2009) Corticosterone in relation to tissue cadmium, mercury and selenium concentrations and social status of male lesser scaup (Aythya affinis). Ecotoxicology 18:5-14. doi:10.1007/s10646-008-0250-9
Qu W, Diwan BA, Liu J, Goyer RA, Dawson T, Horton JL, Cherian HG, Waalkes MP (2002) The metallothionein-null phenotype is associated with heightened sensitivity to lead toxicity and an inability to form inclusion bodies. Am J Pathol 160:1047-1056

Salińska A, Włostowski T, Maciak S, Łaszkiewicz-Tiszczenko B, Kozłowski P (2012) Combined effect of dietary cadmium and benzo(a)pyrene on metallothionein induction and apoptosis in the liver and kidneys of bank voles. Biol Trace Elem Res 147:189-194. doi:10.1007/s12011-011-9279-3

Sanchez-Chardi A, Penarroja-Matutano C, Borras M, Nadal J (2009) Bioaccumulation of metals and effects of a landfill in small mammals. Part III: structural alterations. Environ Res 109: 960-967. doi:10.1016/j.envres.2009.08.004

Satarug S, Baker JR, Urbenjapol S, Haswell-Elkins M, Reilly PEB, Williams DJ, Moore MR (2003) A global perspective on cadmium pollution and toxicity in non-occupationally exposed population. Toxicol Lett 137:65-83. doi:10.1016/S0378-4274 (02)00381-8

Stacey NH, Cantilena LR, Klaassen CD (1980) Cadmium toxicity and lipid peroxidation in isolated rat hepatocytes. Toxicol Appl Pharmacol 53:470-480

Sudo J, Hayashi T, Kimura S, Kakuno K, Terui J, Takashima K, Soyama M (1996) Mechanism of nephrotoxicity induced by repeated administration of cadmium chloride in rats. $\mathbf{J}$ Toxicol Environ Health 48:333-348

Tang W, Sadovic S, Shaikh ZA (1998) Nephrotoxicity of cadmiummetallothionein: protection by zinc and role of glutathione. Toxicol Appl Pharmacol 151:276-282

Thévenod F (2009) Cadmium and cellular signaling cascades: to be or not to be? Toxicol Appl Pharmacol 238:221-239. doi:10.1016/ j.taap.2009.01.013

Thévenod F, Friedmann JM (1999) Cadmium-mediated oxidative stress in kidney proximal tubule cell induced degradation of $\mathrm{Na}^{+} / \mathrm{K}^{+}$-ATP-ase through proteosomal and endo-lysosomal proteolytic pathways. FASEB J 13:1751-1761

Tidhar WL, Bonier F, Speakman JR (2007) Sex- and concentrationdependent effects of predator feces on seasonal regulation of body mass in the bank vole Clethrionomys glareolus. Horm Behav 52:436-444. doi:10.1016/j.yhbeh.2007.06.009

Tietze F (1969) Enzymatic method for the quantitative determination of nanogram amounts of total and oxidized glutathione: application to mammalian blood and other tissues. Anal Biochem 27:502-522

Tort L, Sunyer JO, Gómez E, Molinero A (1996) Crowding stress induces changes in serum haemolytic and agglutinating activity in the gilthead see bream Sparus aurota. Vet Immunol Immunopathol 51:179-188

Vicario M, Guilarte M, Alonso C, Yang PC, Martinez C, Ramos L, Lobo B, González A, Guila M, Pigran M, Saperas E, Azpiroz F, Santos J (2010) Chronological assessment of mast cell-mediated gut dysfunction and mucosal inflammation in a rat model of chronic psychosocial stress. Brain Behav Immun 24:11661175

Vicario M, Alonso C, Guilarte M, Serra J, Martinez C, GonzálezCastro AM, Lobo B, Antolin M, Andreu AL, Garcia-Arumi E, Casellas M, Saperas E, Malagelada JR, Azpiros F, Santos J (2012) Chronic psychosocial stress induces reversible mitochondrial damage and corticotropin-releasing factor receptor type-1 upregulation in the rat intestine and IBS-like gut dysfunctions. Psychoneuroendocrinology 37:65-77. doi:10.1016/j.psyneuen. 2011.05.005

Wang L, Li J, Li J, Liu Z (2010) Effects of lead and/or cadmium on the oxidative damage of rat kidney cortex mitochondria. Biol Trace Elem Res 137:69-78. doi:10.1007/s12011-009-8560-1 
Wang L, Wang H, Li J, Chen D, Liu Z (2011) Simultaneous effects of lead and cadmium on primary cultures of rat proximal tubular cells: interaction of apoptosis and oxidative stress. Arch Environ Contam Toxicol 61:500-511. doi:10.1007/s00244-011-9644-4

Whittaker MH, Wang G, Chen XQ, Lipsky M, Smith D, Gwiazda R, Fowler BA (2011) Exposure to $\mathrm{Pb}, \mathrm{Cd}$, and As mixtures potentiates the production of oxidative stress precursors: 30-day, 90-day, and 180-day drinking water studies in rats. Toxicol Appl Pharmacol 254:154-166. doi:10.1016/j.taap.2010.10.025

Włostowski T, Krasowska A, Łaszkiewicz-Tiszczenko B (2000) Dietary cadmium induces histopathological changes despite a sufficient metallothionein level in the liver and kidneys of the bank vole (Clathrionomys glareolus). Comp Biochem Physiol C 126:21-28. doi:10.1016/S0742-8413(00)00089-X

Włostowski T, Bonda E, Krasowska A (2004) Photoperiod affects hepatic and renal cadmium accumulation, metallothionein induction, and cadmium toxicity in the wild bank vole (Clethrionomys glareolus). Ecotoxicol Environ Saf 58:29-36. doi:10.1016/S0147-6513(03)00109-X

Włostowski T, Dmowski K, Bonda-Ostaszewska E (2010) Cadmium accumulation, metallothionein and glutathione levels, and histopathological changes in the kidneys and liver of magpie (Pica pica) from a zinc smelter area. Ecotoxicology 19:1066-1073. doi:10.1007/s10646-010-0488-x 